\title{
Anal Protrusion Caused by a Ventriculoperitoneal Shunt
}

\author{
Ventriküloperitoneal Şantın Neden Olduğu Anal Protrüzyon
}

\author{
Enver Sosuncu ${ }^{1}$, İsmail Gülşen ${ }^{1, *}$, Nejmi Kıymaz ${ }^{2}$, Kemal Ağengin ${ }^{3}$, Metin Şimşek ${ }^{3}$, Mehmet $^{2}$ \\ Melek $^{3}$
}

${ }^{1}$ Department of Neurosurgery, Yигuncu Yal University, Faculty of Medicine, Van, Turkey

${ }^{2}$ Department of Neurosurgery, Akdeniz University, Faculty of Medicine, Antalya, Turkey

${ }^{3}$ Department of Pediatric Surgery, Yuzuncu Yal University, Faculty of Medicine, Van, Turkey

\begin{abstract}
Ventriculoperitoneal shunt is the most common method used in the treatment of hydrocephalus. Anal protrusion is a rare complication of ventriculoperitoneal shunt occurring after the perforation of intestinal system. If early diagnosis is not established, severe ventriculitis and sepsis may develop ascending infection from gasrointestinal flora migrating thorough the catheter. In the present case, we introduced a patient with anal protrusion of the distal part of a ventriculoperitoneal shunt caused by colon perforation 40 months after the surgery, in whom the catheter was removed by surgical intervention.
\end{abstract}

Key Words: Hydrocephalus, intestinal perforation, ventriculoperitoneal shunt

\section{Introduction}

Ventriculoperitoneal shunt is the most common method which is used in the treatment of hydrocephalus (1-3). Complications of ventriculoperitoneal shunt can be meningitis, mechanical impairment, migration of the catheter, inguinal hernia, perforation of internal organs, peritonitis and protrusion of the ventriculoperitoneal shunt by the anal canal $(4,5)$. Intestinal perforation is a very rare and usually delayed complication. The development of peritonitis or ventriculitis can be a fatal condition (6). In the present case, we introduced a patient in whom the catheter was removed by surgical intervention due to anal protrusion caused by intestinal perforation by the ventriculoperitoneal shunt catheter, 40 months after the placement.

\section{ÖZET}

Hidrosefalinin tedavisinde ventriküloperitoneal şant en yaygın kulanılan cerrahi yöntemdir. Ventrikküloperitoneal şantın peritoneal kateterinin bağırsağ yoldan protrüze olması nadir bir komplikasyondur. Eğer erken tanı konulmazsa, kateter yoluyla taşınan gastrointestinal floradan dolayı şiddetli ventrikülit ve en sonunda sepsis gelişebilir. Bu olguda Hidrosefali tedavisi için ventriküloperitoneal şant takılan 3,5 yaşındaki kız çocuğun 40 ay sonra şantın peritoneal kateterinin kolonu perfore ederek anüsten dışarı çıktığı bir olgu sunulmuştur.

Anahtar Kelimeler: Hidrosefali, intestinal perforasyon, ventriküloperitoneal şant

\section{Case Report}

A $3^{1 / 2}$ years old girl was operated at our hospital during the neonatal term due to occipital encephalocele and a ventriculoperitoneal shunt was inserted for hydrocephalus treatment. Patient was discharged after five days. Patient came to neurosurgery outpatient clinic after 40 months due to high temperature and vomiting. The child was immediately hospitalized with preliminary diagnoses of shunt dysfunction. Antibiotic therapy was initiated. The distal catheter was detected in the anus of the patient at Day 4 of the therapy (Figure 1). In the same day, Enterobacter cloacae and Escherichia coli were produced, respectively at day 4 in blood and CSF samples. Examination revealed that the foreign object was the distal part of the ventriculoperitoneal shunt which had previously 


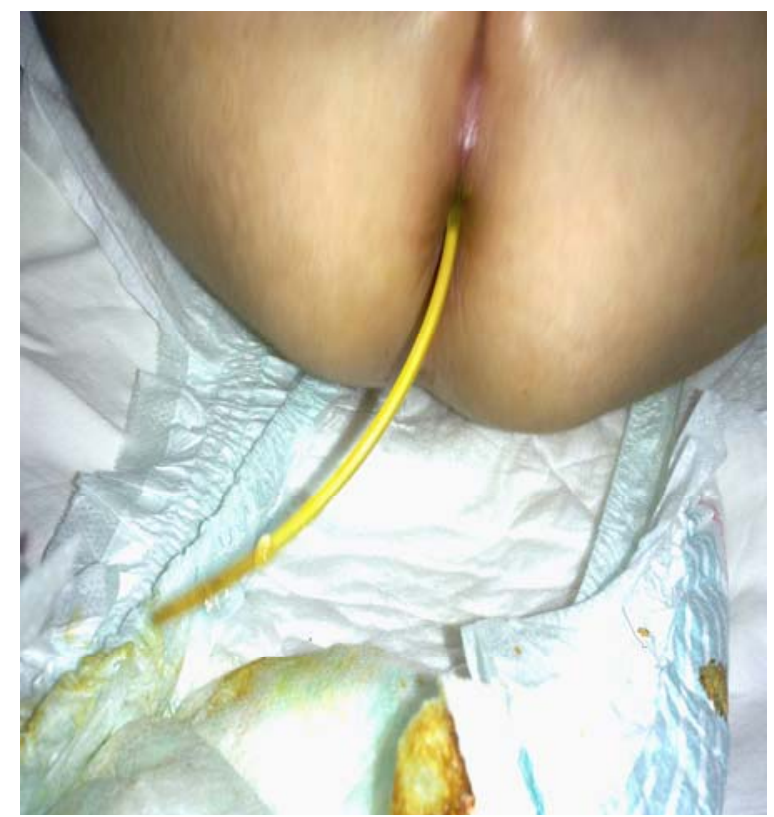

Figure 1. The ventriculoperitoneal shunt's peritoneal catheter was detected in the anus of the

been inserted to the patient. We obtained permission from parents of patient for the operation. The patient was immediately operated in cooperation with the department of pediatric surgery. The ventriculoperitoneal shunt was resected under the right level spring and the distal tip was pulled out from the anus by the surgery team (Figure 2). Then, external ventricular drainage was applied. A new ventriculoperitoneal shunt was re-inserted due to positive response to meningitis treatment and improvement of CSF findings.

\section{Discussion}

Ventriculoperitoneal shunt is most frequent used method for treatment of hydrocephalus. There are shunt complications such as shunt infections, ventricular catheter occlusion, shunt peritoneal edge obstruction, and subdural effusion due to overdrainage. Spontaneous bowel perforation is a rare complication of peritoneal catheter and its incidence is between $0.1-0.7 \%$ in shunted patients (7). The first case was reported in $1996(3,5,8)$. The ventriculitis, meningitis, intraabdominal abscess and generalized peritonitis that occur due to intestinal perforation are life-threating complications (9). The perforation mechanism is not clearly known. Chronic irritation and traumas may be the reason (6). The most common presentation of bowel perforation is extrusion of catheter thorough anus (7). We reported a case of

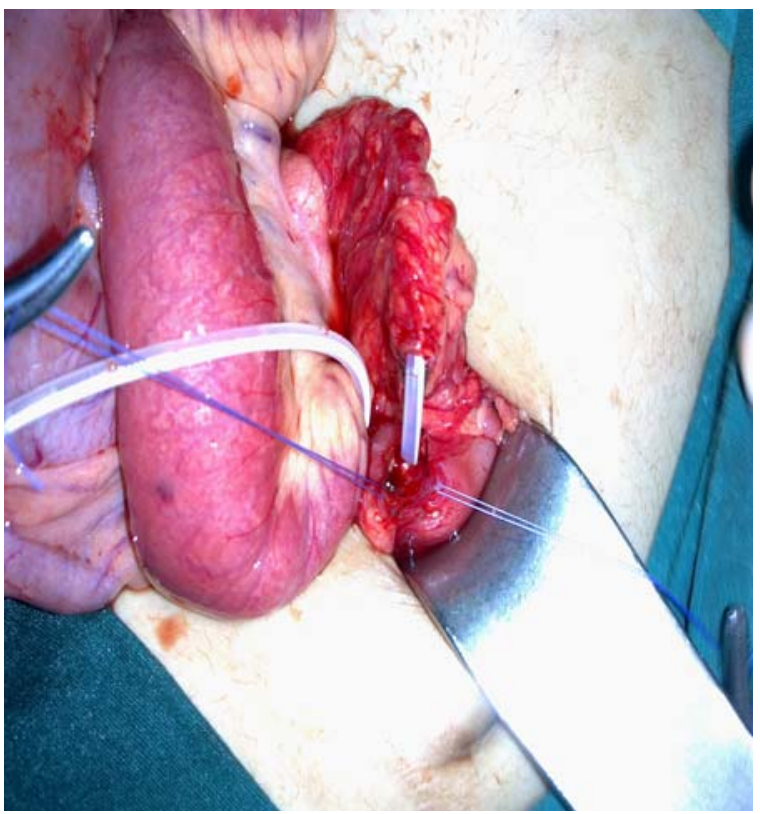

Figure 2. Intra-operative view: The picture of the distal peritoneal catheter, perforating colon.

colonic perforation by ventriculoperitoneal catheter with no tube protruding from the anus.

In early bowel perforation, previous abdominal infections may lead to adhesions and use of toracar to introduce catheter into the peritoneal cavity, therefore, many authors prefer to approach the periton under direct vision. Early stage bowel perforation is result of technical error rather than inflammation. The delayed stage bowel perforation may result from a chronic inflammatory process. Exact pathogenesis of ventriculoperitoneal shunt-related organ perforation is unclear and various mechanisms are suggested, such as foreign body reaction, pressure necrosis and poor general condition with weakening of intestinal wall and stiff end of shunt tube causing intestinal perforation (10). Many authors have stated that unloaded silicon catheters, which do a foreign body-like reaction, are also responsible for bowel perforation $(7,11)$. Di Rocco et al. (10) consider that patients with myelomeningocele may be at increased risk for bowel perforation. These children may be more susceptible to developing perforation due to a weakness in the bowel wall resulting from deficient innervation. Therfore, bowel may be easily perforated by hard-tipped catheters. In light of the literature, the patient's clinical condition and the type of the catheter used may be significant factors. We used a silicon catheter in our case who had an encephalocele. 
Early diagnosis of bowel perforation is essential. Most important finding of intestinal perforation is protrusion of distal shunt catheter from the anus, however diagnosis of bowel perforation is frequently difficult if no anal extrusion of distal catheter exists. Bowel perforation causes obstruction of shunt because of meningitis or ventriculitis; therefore, these patients are referred for shunt failure. Signs of infection along catheter tract is another factor raising suspicion of shunt infection. The abdominal computed tomography scan with contrast and ultrasonography may be helpful, showing location of distal catheter in the periton, local inflammation and thickened muscular layer and mucosa. Endoscopy may reveal perforation site of catheter thorough the colonic wall. If the shunt is not protruded externally, radiography following injection of contrast medium into the shunt system can be used to diagnose bowel perforation. It may be very important to see the catheter extending into the intestinal lumen following injection of contrast medium into the shunt system in the radiograph (11-12).

The treatment of patients who developed intestinal perforation from chronic irritation should include following: removal of the shunt, external drainage and broad spectrum antibiotics, followed by insertion a new peritoneal shunt. The peritoneal catheter should be removed distally and this point is very important in order to avoid the spread of infection to the CNS. An external ventricular drainage should be performed until meningitis or ventriculitis subside and then the shunt should be revised. Atrial shunt is indicated only if abdominal problem is not solved at the time of shunt insertion. Bowel perforation should be prevented as much as possible. Our patient underwent laparotomy. For patients with catheter protruding thorough the anus and no signs of intraabdominal infection, the catheter can be removed safely by pulling thorough the anus.

Familiarity with the possible complication of bowel perforation, along with early diagnosis, is necessary to exclude this rare complication in patients with VP shunts. When bowel perforation is detected at an asymptomatic stage, the prognosis for recovery is excellent, with no deaths being reported in this group. The highest mortality rate is associated with patients who present predominantly with abdominal complications. If bowel perforation can be detected and corrected early on, the patient's prognosis is much better.

\section{References}

1. Acharya R, Ramachandran CS, Singh S. Laparoscopic management of abdominal complications in ventriculoperitoneal shunt surgery. J Laparoendosc Adv Surg Tech A 2001; 11(3): 167-170.

2. Arslan M, Yazıc1 T, Güdü BO, Demir I. Bowel perforation at the delayed stage after shunt surgery: Case report. J Clin Anal Med 2012; 3(1): 109-111.

3. Topuz Ö, Gürcan O, Göker T, Ertan T. Anal Kanaldan Protrüze Olan Ventriküloperitoneal Şantın Laparoskopi Yardımıyla Çıkarılması. Causa Pedia 2012; 1: 198.

4. Glatstein M, Constantini S, Scolnik D, Shimoni N, Roth J. Ventriculoperitoneal shunt catheter protrusion through the anus: case report of an uncommon complication and literature review. Childs Nerv Syst 2011; 27(11): 2011-2014.

5. Seyithanoglu MH, Doğan K, Gundag M, Kitis S, Ozturk S, Dundar T ve ark. VentriküloPeritoneal Şantın Geç Komplikasyonu: Dört Olguda Peritoneal Kateterin Anal Protrüzyonu. Türk Nöroşirürji Dergisi 2011; 21(3): 269-273.

6. Li HN, Tan TC, Cheung FC. Transanal protrusion of ventriculoperitoneal shunt. Surgical Practice 2008; 12(3): 93-96.

7. Gülşen İ, Ak H, Arslan M, Gökalp A, Sosuncu E, Kıymaz N. Çocukluk Çağında Ventriküloperitoneal Şant Disfonksiyonları. Türk Nöroşiruruji Dergisi 2014; 24(3): 280-283.

8. Vinchon M, Baroncini M, Laurent T, Patrick D. Bowel perforation caused by peritoneal shunt catheters: diagnosis and treatment. Neurosurg 2006; 58(1): 76-82.

9. Yılmaz N, Kiymaz N, Yılmaz C, Çaksen H, Yuca SA. Anal protrusion of ventriculo-peritoneal shunt catheter: report of two infants. J Ped Neuro 2004; 2(4): 241-244.

10. Di Rocco C, Marchese E, Vellardi F. A survey of the first complication of newly implanted CSF devices for the treatment of nontumoral hydrocephalus. Childs Nerv Syst 1994; 10(5): 321-327.

11. Jang HD, Kim MS, Lee NH, Kim SH. Anal extrusion of distal V-P shunt catheter after double perforation of large intestine. J Korean Neurosurg Soc 2007; 42(3): 232-234.

12. Borcek AO, Civi S, Golen M, Emmez H, Baykaner MK. An unusual ventriculoperitoneal shunt complication: spontaneous knot formation. Turk Neurosurg 2012; 22(2): 261-264. 